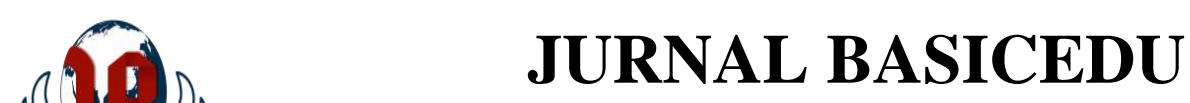

Volume 5 Nomor 2 Tahun 2021 Halaman 1076-1082

Research \& Learning in Elementary Education https://jbasic.org/index.php/basicedu

PAIVRSATAS

\title{
Keterampilan Berpikir Kritis pada Pembelajaran IPA Melalui Model Pembelajaran Discovery Learning Bagi Siswa Sekolah Dasar
}

\author{
Rochmad Ari Setyawan ${ }^{1}$, Hana Septina Kristanti ${ }^{2}$ \\ Pendidikan Profesi Guru, FKIP, Universitas Kristen Satya Wacana, Indonesia ${ }^{1}$ \\ SD Negeri Dukuh 03, Kec. Sidomukti, Salatiga, Indonesia ${ }^{2}$ \\ E-mail: rochmad.ari@gmail.com ${ }^{1}$, hanaseptina86@gmail.com ${ }^{2}$
}

\begin{abstract}
Abstrak
Penelitian dilatar belakangi adanya keterampilan berpikir kritis yang rendah pada pembelajaran pandemic Covid 19. Tujuan penelitian ini adalah untuk mengetahui peningkatan keterampilan berpikir kritis pada pembelajaran IPA melalui model pembelajaran Discovery Learning pada peserta didik kelas 4 SD Negeri Karangduren 01. Penerapan model pembelajaran ini terdapat 6 langkah pembelajaran yaitu stimulus (stimulation), identifikasi masalah (problem statement), pengumpulan data (data collecting), pengolahan data (data processing), verifikasi (verification), generalisasi (generalization). Penelitian ini merupakan jenis penelitian tindakan kelas (PTK). Penelitian dilaksanakan pada Semester 2 Tahun Ajaran 2020/2021 melewati 2 siklus yang dimulai bulan Februari sampai dengan bulan Maret 2021 dengan subjek penelitian peserta didik kelas 4 SD Negeri Karangduren 01 sebanyak 36 siswa. Teknik pengumpulan data dalam penelitian ini adalah non tes berupa observasi dan tes berupa pemberian soal evaluasi dengan teknik analisis data secara kuantitatif dan kualitatif. Berdasarkan penelitian, didapatkan meningkatnya data rata-rata keterampilan berpikir kritis peserta didik dari kondisi awal (pra siklus) yaitu 50,8 dengan kategori rendah menjadi 58,6 dengan kategori tinggi dan meningkat pada siklus II menjadi 84,2 dengan kategori sangat tinggi. Dengan demikian, ditarik simpulan melalui model pembelajaran Discovery Learning dapat meningkatkan keterampilan berpikir kritis pada pembelajaran IPA melalui pada peserta didik kelas 4 SD Negeri Karangduren 01 Semester 2 Tahun Ajaran 2020/2021.
\end{abstract}

Kata Kunci: Berpikir kritis, IPA, Discovery Learning, Kelas 4.

\begin{abstract}
The research was based on the low critical thinking skills in learning the Covid 19 pandemic. The purpose of this study was to determine the increase in critical thinking skills in science learning through the Discovery Learning learning model for 4th grade students of SD Negeri Karangduren 01. The application of this learning model consists of 6 steps. learning, namely stimulus (stimulation), problem identification (problem statement), data collection (data collecting), data processing (data processing), verification (verification), generalization (generalization). This research is a type of classroom action research (PTK). The research was carried out in Semester 2 of the 2020/2021 academic year through 2 cycles starting from February to March 2021 with the research subjects of grade 4 students of SD Negeri Karangduren 01 as many as 36 students. Data collection techniques in this study were non-tests in the form of observations and tests in the form of giving evaluation questions with quantitative and qualitative data analysis techniques. Based on the research, it was found that the average data of critical thinking skills of students from the initial condition (pre-cycle) was 50.8 with a low category to 58.6 with a high category and an increase in the second cycle to 84.2 with a very high category. Thus, a conclusion was drawn that through the Discovery Learning learning model it could improve critical thinking skills in science learning through grade 4 students at SD Negeri Karangduren 01 Semester 2 in the 2020/2021 academic year.
\end{abstract}

Keywords: Critical thinking, Science, Discovery Learning, Grade 4.

Copyright (c) 2021 Rochmad Ari Setyawan, Hana Septina Kristanti

Corresponding author :

Email: :rochmad.ari@gmail.com

DOI : https://doi.org/10.31004/basicedu.v5i2.877

ISSN 2580-3735 (Media Cetak)

ISSN 2580-1147 (Media Online)

Jurnal Basicedu Vol 5 No 2 Tahun 2021

p-ISSN 2580-3735 e-ISSN 2580-1147 
1077 Keterampilan Berpikir Kritis Pada pembelajaran IPA Melalui Model Pembelajaran Discovery Learning Bagi Siswa Sekolah Dasar - Rochmad Ari Setyawan, Hana Septina kristanti

DOI : https://doi.org/10.31004/basicedu.v5i2.877

\section{PENDAHULUAN}

Seluruh dunia saat ini sedang mengalami pandemi Covid 19 yang berdampak pada kehidupan seharihari. Segala aspek kegiatan masyarakat mengalami dampak ini. Salah satu aspek yang terdampak akibat pandemi adalah bidang pendidikan. Salah satu upaya guna pencegahan virus Covid 19 adalah dengan adanya pembatasan kegiatan bermasyarakat. Menurut Inmendagri (2021), bahwa proses kegiatan belajar mengajar guna memberikan pengalaman belajar yang bermakna dilaksanakan dengan tetap membatasi kegiatan masyarakat dilakukan secara daring atau jarak jauh. Menurut Abidin et al., (2020) pembelajaran jarak jauh merupakan suatu kegiatan belajar tanpa kontak langsung antara peserta didik dengan pendidik melalui media radio, video, komputer, dan internet. Dalam pembelajaran saat ini, Kepmendikbud (2020) menetapkan kurikulum dilakukan penyederhanaan guna kondisi khusus secara mandiri dengan memperhatikan prinsip pembelajaran. Kurikulum yang sedang berjalan saat ini sistem pembelajaran kurikulum 2013.

Pembelajaran kurikulum 2013 merupakan pembelajaran yang bersifat tematik. Pembelajaran tematik merupakan pembelajaran yang berkesinambungan. Pembelajaran tematik cenderung melibatkan peserta didik baik secara mental maupun secara fisik dalam kegiatan pembelajaran. Pembelajaran tematik ini, terdiri dari beberapa muatan pelajaran, salah satunya adalah muatan pembelajaran IPA. IPA merupakan proses mencari dan proses berpikir kreatif berbagai sebab akibat dari berbagai fenomena yang ada di alam (Acesta, 2014). Ilmu Pengetahuan Alam (IPA) merupakan ilmu yang dikembangkan oleh para ahli guna mempelajari alam semesta beserta isinya (Sujana, 2014). Setyawan et al., (2019) mengemukakan bahwa IPA merupakan suatu muatan yang diperoleh berdasarkan hasil eksperimen dan penyimpulan dari peristiwa yang terjadi di lingkungan sekitar.

Berdasarkan pendapat dari berbagai ahli tersebut dapat disimpulkan bahwa Ilmu Pengetahuan Alam (IPA) adalah proses kreatif dan mencari perbagai sebab akibat dari berbagai fenomena-fenomena yang mempelajari alam semesta beserta isinya, serta peristiwa-peristiwa yang terjadi didalamnya yang dikembangkan oleh para ahli melalui serangkaian proses ilmiah yang dilakukan secara teliti dan hati-hati.

Pembelajaran IPA mengembangkan keterampilan proses dan sikap ilmiah peserta didik. Sehingga mampu mematik kemampuan berpikir peserta didik. Hal ini sejalan dengan pendapat Rafianti et al., (2018) dimana kurikulum 2013 ini menekankan pada keterampilan HOTS (High Order Thinking Skill) dan keterampilan 4C (Creative, Critical thingking, Communicative, Collaborative). Keterampilan ini memiliki prinsip pembelajaran yang bersifat student centered atau berpusat kepada peserta didik. Hal ini dibutuhkan keterampilan salah satunya adalah keterampilan berpikir kritis (Critical Thinking).

Ennis berpendapat bahwa berpikir kritis merupakan suatu proses berpikir guna membuat keputusan mengenai apa yang akan diyakini dan apa yang akan dilakukan yang dapat dipertanggungjawabkan (Abdullah, 2016). Kemudian menurut Susanto (2013) mengemukakan bahwa berpikir kritis merupakan suatu kemampuan berpikir pada taraf tinggi yang terdiri dari analisis masalah, mengenal masalah, melakukan pemecahan masalah, menyimpulkan serta mengevaluasi.

Berdasarkan pendapat dari beberapa ahli diatas dapat ditarik sebuah kesimpulan bahwa berpikir kritis merupakan suatu proses berpikir tingkat tinggi guna membuat keputusan-keputusan yang berdasarkan hasil analisis masalah, mengenal masalah, melakukan pemecahan masalah, menyimpulkan serta mengevaluasi masalah tersebut.

Observasi yang dilakukan peneliti terhadap 36 peserta didik kelas 4 SD Negeri Karangduren 01 Kecamatan Tengaran Kabupaten Semarang menunjukkan bahwa kemampuan keterampilan berpikir kritis peserta didik pada muatan IPA masih tergolong rendah. Hasil observasi keterampilan berpikir kritis pada pra siklus didapatkan data sebanyak 0 peserta didik (0\%) dengan kategori sangat tinggi, 14 peserta didik (39\%) 
1078 Keterampilan Berpikir Kritis Pada pembelajaran IPA Melalui Model Pembelajaran Discovery Learning Bagi Siswa Sekolah Dasar - Rochmad Ari Setyawan, Hana Septina kristanti

DOI : https://doi.org/10.31004/basicedu.v5i2.877

dengan kategori tinggi, 22 peserta didik $(61 \%)$ dengan kategori rendah dan 0 peserta didik $(0 \%)$ dengan kategori sangat rendah. Rata-rata sebanyak 50,8 dengan kategori keterampilan berpikir kritis rendah. Hal ini dikarenakan adanya pembelajaran daring yang kurang maksimal karena hanya menggunakan Whatsapp Group dan juga terbatasnya perangkat pendukung peserta didik. Mengingat hal tersebut, diperlukan sebuah model pembelajaran yang dapat diterapkan kepada peserta didik meskipun dalam kondisi pandemi Covid 19. Selain itu, model pembelajaran tersebut juga membantu untuk meningkatkan keterampilan berpikir kritis pada pembelajaran IPA siswa kelas 4 SD Negeri Karangduren 01.

Salah satu model pembelajaran yang dapat digunakan untuk meningkatkan keterampilan berpikir kritis pada masa pandemi Covid 19 adalah dengan menggunakan model pembelajaran Discovery Learning. Model pembelajaran Discovery Learning dilakukan dengan menerapkan 6 tahapan pembelajaran yaitu (1) stimulus (stimulation), (2) identifikasi masalah (problem statement), (3) pengumpulan data (data collecting), (4) pengolahan data (data processing), (5) verifikasi (verification), (6) generalisasi (generalization) (Rafianti et al., 2018). Hosnan (2016) mengemukakan bahwa model pembelajaran Discovery Learning merupakan model pembelajaran yang dapat mengembangkan cara belajar siswa aktif dengan menemukan sendiri, menyelidiki sendiri, maka hasil yang akan diperoleh siswa dapat bertahan lama dalam ingatan, tidak akan mudah dilupakan oleh siswa. Hamalik (2011) berpendapat model pembelajaran Discovery Learning merupakan strategi pembelajaran yang berpusat pada siswa dimana peserta didik dibawa pada satu permasalahan atau mencari jawaban dengan prosedur dan struktur secara jelas. Kadri \& Rahmawati (2015) menambahkan bahwa model pembelajaran Discovery Learning adalah model pembelajaran yang menekankan kepada pentingnya pemahaman struktur, atau ide-ide yang penting terhadap suatu disiplin ilmu melalui keterlibatan siswa secara aktif dalam kegiatan pembelajaran.

Berdasarkan pendapat ahli diatas, maka disimpulkan bahwa model pembelajaran Discovery Learning adalah suatu model pembelajaran yang dapat mengembangkan cara belajar siswa aktif dengan menemukan sendiri, menyelidiki sendiri yang dalam pelaksanaannya berpusat pada siswa dimana kelompok-kelompok siswa dibawa kedalam suatu persoalan untuk mencari jawaban dengan menekankan kepada pentingnya pemahaman struktur, atau ide-ide yang penting terhadap suatu disiplin ilmu melalui keterlibatan siswa secara aktif dalam kegiatan pembelajaran.

Beberapa penelitian menunjukkan peningkatan keterampilan berpikir kritis melalui penerapan model pembelajaran Discovery Learning. Salah satunya oleh Hidayat et al (2019) menunjukkan keterampilan berpikir kritis dan hasil belajar peserta didik dengan berbantuan model Discovery Learning meningkat dengan signifikan. Persentase kemampuan berpikir kritis sebesar 71,4\% pada siklus I dan mengalami peningkatan menjadi $80,9 \%$ pada siklus II. Sejalan dengan penelitian tersebut, penelitian tentang peningkatan keterampilan berpikir kritis dan hasil belajar pada siswa kelas 4 SD N Karangduren 02 menunjukkan peningkatan berpikir kritis dengan persentase kategori sangat tinggi sebesar 22\% pada siklus I menjadi sebesar $63 \%$ pada kategori sangat tinggi siklus II (Rahayu dkk, 2019).

Tujuan penelitian ini adalah : (1) mendeskripsikan langkah-langkah penerapan model pembelajaran Discovery Learning dalam meningkatkan keterampilan berpikir kritis pada pembelajaran IPA pada peserta didik kelas 4 SD Negeri Karangduren 01, (2) mengetahui peningkatan keterampilan berpikir kritis pada pembelajaran IPA melalui model pembelajaran Discovery Learning pada peserta didik kelas 4 SD Negeri Karangduren 01.

Berdasarkan tujuan penelitian yang telah diungkapkan oleh peneliti diatas maka disusun hipotesis tindakan dari penelitian ini adalah : (1) melalui penerapan langkah-langkah pembelajaran yang terdapat pada model pembelajaran Discovery Learning yang meliputi stimulus (stimulation), identifikasi masalah (problem statement), pengumpulan data (data collecting), pengolahan data (data processing), verifikasi (verification), 
1079 Keterampilan Berpikir Kritis Pada pembelajaran IPA Melalui Model Pembelajaran Discovery Learning Bagi Siswa Sekolah Dasar - Rochmad Ari Setyawan, Hana Septina kristanti

DOI : https://doi.org/10.31004/basicedu.v5i2.877

generalisasi (generalization) dapat meningkatkan keterampilan berpikir kritis pada pembelajaran IPA melalui model pembelajaran Discovery Learning pada peserta didik kelas 4 SD Negeri Karangduren 01 pada Semester 2 Tahun Ajaran 2020/2021, (2) melalui penerapan model pembelajaran Discovery Learning dapat meningkatkan keterampilan berpikir kritis pada pembelajaran IPA melalui model pembelajaran Discovery Learning pada peserta didik kelas 4 SD Negeri Karangduren 01 pada Semester 2 Tahun Ajaran 2020/2021.

\section{METODE PENELITIAN}

Peneliti menggunakan jenis penelitian tindakan kelas atau PTK pada penelitian ini. PTK digunakan guna memperbaiki pembelajaran tematik integratif (Mawardi, 2014). Selain itu, PTK merupakan kegiatan untuk mengamati kejadian dalam pembelajaran di kelas guna memperbaiki hasil belajar menjadi lebih baik dalam proses pembelajaran (Bahri, 2012). Penelitian Tindakan Kelas ini dilakukan dengan beberapa siklus menggunakan model Stringer. Setiap siklus terdiri dari beberapa prosedur, yaitu (1) melihat (Look), (2) berfikir (Think), dan (3) bertindak (Act). Prosedur pada setiap siklus saling berkesinambungan.

Prosedur pertama adalah melihat dimana tahap ini melakukan kegiatan pengumpulan data melalui observasi dan wawancara antara peneliti dengan guru kelas serta melakukan identifikasi masalah yang ada. Selanjutnya pada prosedur berfikir meliputi perencanaan pembelajaran dan menentukan indikator hasil belajar. Prosedur ketiga yaitu bertindak dimana pada tahap ini dilakukan pengaplikasian yang telah direncanakan.

Penelitian dilaksanakan di SD Negeri Karangduren 01 semester 2 tahun ajaran 2020/2021. SD Negeri Karangduren 01 berada di Desa Karangduren, Kecamatan Tengaran, Kabupaten Semarang. SD Negeri Karangduren 01 berdekatan dengan SMP N 2 Tengaran dan SMK N 1 Tengaran. Subjek penelitian ini adalah peserta didik kelas 4 SD Negeri Karangduren 01 yang berjumlah 36 peserta didik. Penelitia bekerjasama dengan guru kelas 4 SD Negeri Karangduren 01, yaitu Bapak Sugiyarto, S.Pd dalam melakukan penelitian ini.

Peneliti melakukan pengumpulan data dengan menggunakan teknik tes dan teknik non tes. Teknik tes berupa rubrik penilaian untuk mengukur tingkat keterampilan berpikir kritis peserta didik. Peneliti menggunakan indikator penilaian yang telah disesuaikan dengan materi dan karakteristik peserta didik. Sistem penilaian pada rubrik penilaian ini ialah setiap 1 item mendapat skor maksimal 4 poin. Adapun skor maksimal total rubrik ialah 20 poin. Rubrik ini telah dilakukan uji validitas menggunakan SPSS versi 23.

Sedangkan untuk teknik non tes peneliti menggunakan lembar observasi guru dan peserta didik. Isi dari lembar observasi ialah implementasi pembelajaran IPA dengan menggunakan prosedur pembelajaran Discovery Learning. Lembar observasi dilakukan sebelum proses pembelajaran berakhir. Analisis data yang digunakan dalam penelitian ini adalah analisis kuantitatif dan deskripsi komparatif. Peneliti melakukan perbandingan ketika Pra Siklus, Siklus I, dan Siklus II. Indikator keberhasilan dalam penelitian ini ditandai dengan adanya peningkatan keterampilan berpikir kritis peserta didik sebelum diterapkan model pembelajaran Discovery Learning dan setelah diterapkan model pembelajaran Discovery Learning. Keterampilan berpikir kritis dikatakan meningkat apabila lebih dari $70 \%$ peserta didik berada pada kategori sangat tinggi.

\section{HASIL DAN PEMBAHASAN}

Peneliti melaksanakan penelitian ini dalam dua siklus. Setiap siklus merupakan satu kali pertemuan dengan alokasi waktu 3 x 30 menit. Dibawah ini adalah tabel peningkatan keterampilan berpikir kritis pada pembelajaran IPA melalui model pembelajaran Discovery Learning pada peserta didik kelas 4 SD Negeri Karangduren 01. 

Learning Bagi Siswa Sekolah Dasar - Rochmad Ari Setyawan, Hana Septina kristanti

DOI : https://doi.org/10.31004/basicedu.v5i2.877

Tabel 1. Perbandingan Hasil Keterampilan Berpikir Kritis Peserta Didik Kelas 4

\begin{tabular}{|c|c|c|c|c|c|c|c|}
\hline \multirow{2}{*}{ No } & \multirow{2}{*}{$\begin{array}{c}\text { Kualifikasi } \\
\text { Tingkat Berpikir }\end{array}$} & \multicolumn{2}{|c|}{ Pra Siklus } & \multicolumn{2}{c|}{ Siklus I } & \multicolumn{2}{c|}{ Siklus II } \\
\cline { 3 - 8 } & & F & $\mathbf{\%}$ & F & \% & F & $\%$ \\
\hline 1. & Sangat Tinggi & 0 & $0 \%$ & 4 & $11 \%$ & 30 & $83 \%$ \\
\hline 2. & Tinggi & 14 & $39 \%$ & 17 & $47 \%$ & 6 & $17 \%$ \\
\hline 3. & Rendah & 22 & $61 \%$ & 15 & $42 \%$ & 0 & $0 \%$ \\
\hline 4. & Sangat Rendah & 0 & $0 \%$ & 0 & $0 \%$ & 0 & $0 \%$ \\
\hline
\end{tabular}

Dari tabel 1 di atas menunjukkan data hasil keterampilan berpikir kritis pada pra siklus sebanyak 14 peserta didik pada kategori tinggi dengan persentase 39\% dan sebanyak 22 peserta didik pada kategori rendah dengan persentase 61\%. Dapat diketahui pada siklus I mengalami peningkatan menjadi 4 peserta didik memiliki keterampilan berpikir kritis pada kategori sangat tinggi, 17 peserta didik pada kategori tinggi, 15 peserta didik pada kategori rendah. Pada siklus II mengalami peningkatan dari pada siklus sebelumnya. Terdapat 30 peserta didik pada kategori sangat tinggi dan 6 peserta didik pada kategori tinggi.

Tabel 2. Skor Keterampilan Berpikir Kritis Pada Pra Siklus, Siklus I, dan Siklus II.

\begin{tabular}{|c|c|c|c|}
\hline & Pra Siklus & Siklus I & Siklus II \\
\hline Skor Tertinggi & 70 & 85 & 95 \\
\hline Skor Terendah & 30 & 40 & 70 \\
\hline Rata-rata & 50,8 & 58,6 & 84,2 \\
\hline Kategori & Rendah & Tinggi & Sangat Tinggi \\
\hline
\end{tabular}

Berdasarkan pada tabel 2 diatas dapat disimpulkan bahwa hasil skor keterampilan berpikir kritis peserta didik mulai dari pra siklus, siklus I, siklus II rata-rata keterampilan berpikir kritis peserta didik mengalami peningkatan. Hal itu terbukti dengan data pada saat kondisi awal atau pra siklus rata-rata keterampilan berpikir kritis peserta didik adalah 50,8 dengan skor tertinggi 70 dan skor terendah 30 kategori rendah. Setelah diterapkan model pembelajaran Discovery Learning rata-rata keterampilan berpikir kritis peserta didik mengalami peningkatan pada siklus I menjadi sebesar 58,6 dengan nilai tertinggi 85 dan nilai terendah 40 kategori tinggi, kemudian karena belum mencapai indikator keberhasilan yang ditetapkan maka dilaksanakan siklus II dengan hasil rata-rata keterampilan berpikir kritis peserta didik meningkat menjadi 84,2 dengan nilai tertinggi adalah 95 dan nilai terendah adalah 70 dengan kategori tinggi sekali.

Penelitian yang dilaksanakan pada peserta didik kelas 4 SD Negeri Karangduren 01 dengan menggunakan model pembelajaran Discovery Learning terlihat dapat meningkatkan keterampilan berpikir kritis peserta didik pada pembelajaran IPA. Hal tersebut didukung dengan data peningkatan rata-rata keterampilan berpikir kritis peserta didik mulai dari pra siklus, siklus I, sampai siklus II. Pada saat kondisi awal atau pra siklus rata-rata keterampilan berpikir kritis peserta didik adalah 50,8 dengan kategori keterampilan berpikir kritis rendah. Setelah diterapkan model pembelajaran Discovery Learning rata-rata keterampilan berpikir kritis peserta didik mengalami peningkatan pada siklus I menjadi sebesar 58,6 dengan kategori keterampilan berpikir kritis tinggi, kemudian siklus II meningkat lagi menjadi 84,2 dengan kategori keterampilan berpikir kritis tinggi sekali. 
1081 Keterampilan Berpikir Kritis Pada pembelajaran IPA Melalui Model Pembelajaran Discovery Learning Bagi Siswa Sekolah Dasar - Rochmad Ari Setyawan, Hana Septina kristanti

DOI : https://doi.org/10.31004/basicedu.v5i2.877

Hasil penelitian ini didukung dengan penelitian Utami, (2017) yang melakukan penelitian dengan tujuan untuk mendeskripsikan pemahaman konsep IPA dan keterampilan berpikir kritis peserta didik kelas 9 SMP Negeri 2 Kota Blitar. Berdasarkan penelitian ini, menunjukkan keterampilan berpikir kritis peserta didik pada saat diterapkan model pembelajaran Discovery Learning terjadi peningkatan yang signifikan. Sehingga dapat dikatakan melualui model Discovery Learning dapat meningkatkan eterampilan berpikir kritis peserta didik dan pemahaman IPA peserta didik. Penelitian lain juga dilakukan oleh Mawardi \& Mariati (2016) yang menunjukkan keefektifan model Discovery Learning untuk meningkatkan hasil belajar IPA peserta didik. Hal ini dapat dikatakan bahwa model pembelajaran Discovery Learning dapat meningkatkan keterampilan berpikir kritis peserta didik dan berpengaruh pada hasil belajar peserta didik. Sejalan dengan hal tersebut, model pembelajaran tersebut dapat mencapai tujuan pembelajaran. Hal ini membuktikan bahwa efektifitas model pembelajaran secara potensial karena dapat mencapai tujuan pembelajaran (Mawardi, 2018).

\section{KESIMPULAN}

Berdasarkan hasil penelitian yang telah dilaksanakan pada peserta didik kelas 4 di SD Negeri Karangduren 01 pada tahun pelajaran 2020/2021 menggunakan model pembelajaran Discovery Learning, maka dapat ditarik kesimpulan bahwa : (1) penerapan langkah-langkah model pembelajaran Discovery Learning yaitu stimulus (stimulation), identifikasi masalah (problem statement), pengumpulan data (data collecting), pengolahan data (data processing), verifikasi (verification), dan generalisasi (generalization) dapat meningkatkan keterampilan berpikir kritis pada pembelajaran IPA pada peserta didik kelas 4 SD Negeri Karangduren 01, (2) hasil penelitian menunjukkan bahwa terjadi peningkatan terhadap keterampilan berpikir kritis pada pembelajaran IPA melalui model pembelajaran Discovery Learning pada peserta didik kelas 4 SD Negeri Karangduren 01. Hal itu terbukti dengan data pada saat kondisi awal atau pra siklus rata-rata keterampilan berpikir kritis peserta didik adalah 50,8 dengan skor tertinggi 70 dan skor terendah 30 kategori rendah. Setelah diterapkan model pembelajaran Discovery Learning rata-rata keterampilan berpikir kritis peserta didik mengalami peningkatan pada siklus I menjadi sebesar 58,6 dengan nilai tertinggi 85 dan nilai terendah 40 kategori tinggi, kemudian karena belum mencapai indikator keberhasilan yang ditetapkan maka dilaksanakan siklus II dengan hasil rata-rata keterampilan berpikir kritis peserta didik meningkat menjadi 84,2 dengan nilai tertinggi adalah 95 dan nilai terendah adalah 70 dengan kategori tinggi sekali. Dengan demikian, dapat disimpulkan melalui model pembelajaran Discovery Learning dapat meningkatkan keterampilan berpikir kritis peserta didik kelas 4 SD Negeri Karangduren 01 pada pembelajaran IPA Semeseter 2 Tahun Ajaran 2020/2021.

\section{UCAPAN TERIMA KASIH}

Penulis sekaligus peneliti mengucapkan puji syukur kepada Allah SWT atas limpahan Rahmat dan Ridho-Nya dalam proses penelitian ini. Peneliti mengucapkan terimakasih kepada kedua orang tua beserta keluarga yang telah memberikan dukungan secara moral dan materiil. Terima kasih kepada bapak/ibu Dosen Pendidikan Profesi Guru Universitas Kristen Satya Wacana serta guru dan staf SD Negeri Karangduren 01 yang telah memberikan bimbingan dan arahannya. Semoga penelitian ini dapat bermanfaat bagi kita semua. Serta berbagai pihak yang telah mendukung peneliti.

\section{DAFTAR PUSTAKA}

Abdullah, I. H. (2016). Berpikir Kritis Matematika. Delta-Pi: Jurnal Matematika Dan Pendidikan 
1082 Keterampilan Berpikir Kritis Pada pembelajaran IPA Melalui Model Pembelajaran Discovery Learning Bagi Siswa Sekolah Dasar - Rochmad Ari Setyawan, Hana Septina kristanti

DOI : https://doi.org/10.31004/basicedu.v5i2.877

Matematika, 2((1)), 10-17.

Abidin, Z., Hudaya, A., \& Anjani, D. (2020). Efektivitas Pembelajaran Jarak Jauh Pada Masa Pandemi Covid-

19. Research and Development Journal of Education, 1(1), 131. https://doi.org/10.30998/rdje.v1i1.7659

Acesta, A. (2014). Penerapan Pendekatan Keterampilan Proses Sains Untuk Meningkatkan Hasil Belajar Siswa Dalam Pembelajaran Ipa. Jurnal Ilmiah Pendidikan Dasar UNISSULA, 1(2), 96764. https://doi.org/10.30659/pendas.1.2.

Bahri, A. (2012). Penelitian Tindakan Kelas. Universitas Muhammadiyah Makassar.

Hamalik, O. (2011). Kurikulum dan Pembelajaran. Bumi Aksara.

Hidayat, T., Mawardi, M., \& Astuti, S. (2019). Peningkatan Kemampuan Berpikir Kritis Dan Hasil Belajar Siswa Kelas IV Melalui Model Pembelaran Discovery Learning Pada Tema Indahnya Keberagamandi Negeriku. Judika (Jurnal Pendidikan Unsika), 7(1), 1-9.

Hosnan, M. (2016). Pendekatan Saintifik dan Kontekstual dalam Pembelajaran Abad 21. Ghalia Indonesia.

Inmendagri. (2021). INMENDAGRI NOMOR 3 TAHUN 2021.pdf. Kementrian Dalam Negeri.

Kadri, M., \& Rahmawati, M. (2015). Pengaruh Model Pembelajaran Discovery Learning Terhadap Hasil Belajar Siswa Pada Materi Pokok Suhu Dan Kalor. Jurnal Ikatan Alumni Fisika, 1(1), 21. https://doi.org/10.24114/jiaf.v1i1.2692

Kepmendikbud. (2020). Kepmendikbud No 719/P/2020 Tentang Pedoman Pelaksanaan Kurikulum Pada Satuan Pendidikan Dalam Kondisi Khusus. Kementrian Pendidikan dan Kebudayaan.

Mawardi. (2014). Pemberlakuan Kurikulum SD/MI Tahun 2013 Dan Implikasinya Terhadap Upaya Memperbaiki Proses Pembelajaran Melalui PTK. Scholaria : Jurnal Pendidikan Dan Kebudayaan, 4(3), 107. https://doi.org/10.24246/j.scholaria.2014.v4.i3.p107-121

Mawardi. (2018). Merancang Model dan Media Pembelajaran. Scholaria: Jurnal Pendidikan Dan Kebudayaan, 8(1), 26-40. http://ejournal.uksw.edu/scholaria/article/view/1412

Mawardi, \& Mariati. (2016). Komparasi Model Pembelajaran Discovery Learning Dan Problem Solving Ditinjau Dari Hasil Belajar Ipa Pada Siswa Kelas 3 Sd Di Gugus Diponegoro - Tengaran. Scholaria: Jurnal Pendidikan Dan Kebudayaan, 6(1), 127. https://doi.org/10.24246/j.scholaria.2016.v6.i1.p127-142

Rafianti, I., Setiani, Y., \& Novaliyosi, N. (2018). Profil Kemampuan Literasi Kuantitatif Calon Guru Matematika. Jurnal Penelitian Dan Pembelajaran Matematika, 11(1). https://doi.org/10.30870/jppm.v11i1.2985

Setyawan, R. A., Kristin, F., \& Anugraheni, I. (2019). Peningkatan Keaktifan dan Hasil Belajar IPA Siswa Kelas 5 SD Melalui Penerapan Model Pembelajaran Teams Games Tournament. 3(1), 187-193.

Sujana, A. (2014). Dasar-Dasar IPA: Konsep dan Aplikasinya. UPI Press.

Susanto, A. (2013). Teori Belajar dan Pembelajaran di Sekolah Dasar. PT. Kharisma Putra Utama.

Utami, M. (2017). Penerapan Strategi Discovery Learning (DL) Untuk Meningkatkan Keterampilan Berpikir Kritis Dan Pemahaman Konsep IPA. JINoP (Jurnal Inovasi Pembelajaran), 3(1), 483-490. http://202.52.52.22/index.php/jinop/article/view/4317 